\title{
Measurements of air pollution due to the traffic in Bonaparte Street in Paris
}

\author{
G. Maignant \\ UMR 6012 ESPACE, CNRS, Nice, France
}

\begin{abstract}
The purpose of this article is to show how the dispersion of air pollutants in a street canyon could be evaluated (we take as an example Bonaparte Street in the 6th district of Paris) so as to estimate the pollutants concentrations in all points even if there are no stations of measurement. This study, which was made for Airparif, is based on a three dimensional air dispersion model called MISKAM. It is a case study. The model is a non-hydrostatic eulerian dispersion model, which means that it is able to evaluate turbulence created by urban morphology. The model includes emissions, urban morphology (buildings in three dimensions, roughness), climatology (wind direction and amplitude, turbulence). The eulerian model consists of an anisotropic grid, centred on the street being studied. The domain size is $450 \mathrm{~m}$ wide $\times 450 \mathrm{~m}$ long $\times 500 \mathrm{~m}$ high, which means 178200 cells. The model solves the equations of the mechanics of fluids (Navier-Stokes) for each cell of the domain. All the steps of the model are described and discussed. The paper will describe all the data and their uncertainty. The quality of the model will be discussed: the purpose of the model is to give information about air pollutants concentrations within short laps of time, in all places even if there is no data available. The influence of parameters, such as wind speed and direction, on air pollutants concentrations is shown. Finally the results of two models: a complex one and a simple one are compared, the main purpose is to make an operational tool to predict air concentrations in time.
\end{abstract}

Keywords: Air pollution, concentrations, dispersion, measurements, models, Street Canyon, urban morphology, wind field.

\section{Introduction}

This study aims to investigate the possibility of creation of a viable instrument which could measure in almost real time (average hours) the concentrations of 
air pollution in a street. The experiment was carried out in a street in Paris where Airparif, the agency in charge of the supervision of the air quality in Paris, has a specific air measurements site. The exact name of the street is Bonaparte and it is situated in the $6^{\text {th }}$ district of the capital. The characteristic of this street is the fact that it is a canyon street which means it facilitates the concentration of the pollutants. In order to realize this project we will need different kinds of data as follows: topographic data, weather data (wind direction and intensity, humidity, number of rainy days...), traffic data (flow, modal composition) and background pollution data. In spite of many series of measurements, these data are full of uncertainty. Our simulations results will be compared to the results of the air measurement site located in Bonaparte Street. The numerous measurements effectuated by this agency between December $4^{\text {th }}$ and December $7^{\text {th }}, 2000$, consisted in collecting information about pollutants concentrations and about wind velocity and direction measured hourly. This information was provided by a weather mast situated at four metres height.

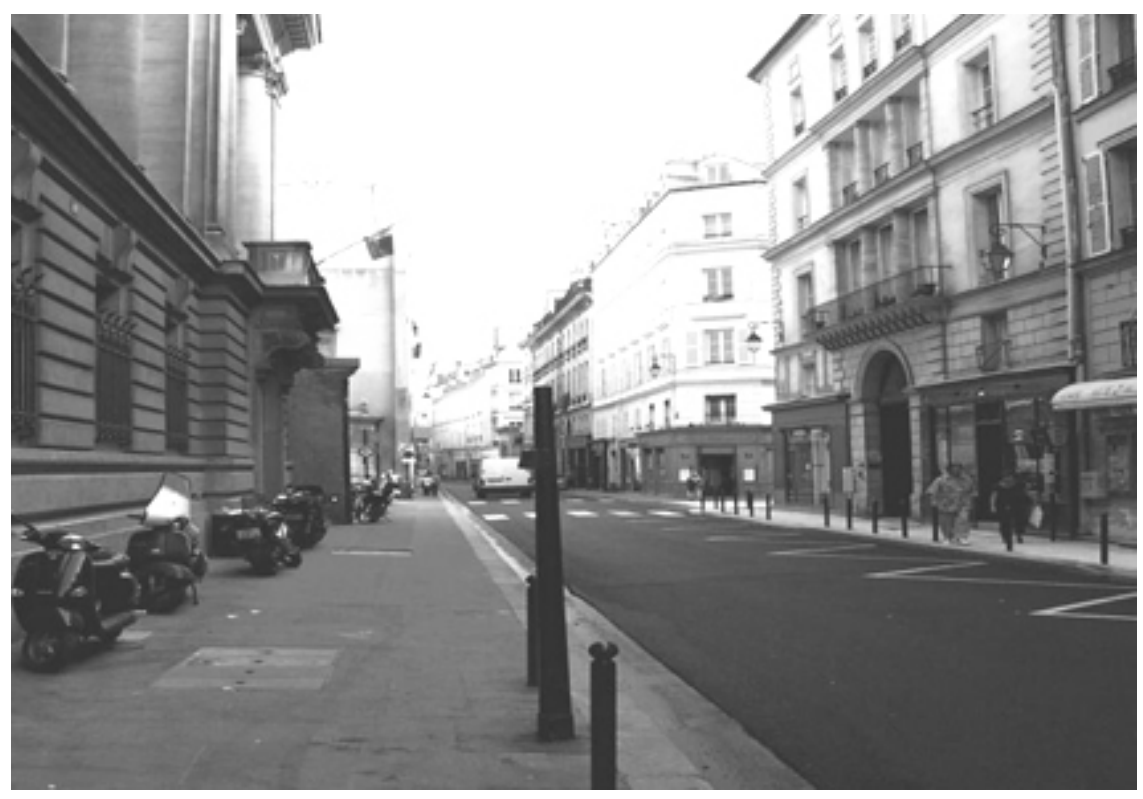

Figure 1: Bonaparte Street in Paris (stereotype: Marjorie Brou, Kisters France SAS).

\section{MISKAM model: principle of operation}

MISKAM (Mikroskaliges Klima und Ausbreitungsmodell) means in German "climate and diffusion model at a local scale". Miskam is a three - dimensional non-hydrostatic model for modelling wind velocity and pollutants concentrations at the scale of a building, a street or a district. The non - hydrostatic characteristic means that this model is able to take into account turbulence 
phenomena generated by the buildings. The programme was created at two levels: at the first level the model can evaluate wind direction and intensity and at the second level it allows us to calculate pollutants concentration according to wind data obtained at the previous level. Two types of equations are the physical base of this model: three-dimensional equations concerning the fluid mechanics (Navier-Stokes equations) and the advection and diffusion equation which can calculate the substances concentrations. The space is indented as elementary cells for which two pieces of information are calculated (wind speed and direction, pollutants concentrations).

The methodology presented in this article is articulated in two steps. The first one aims to realize a modelisation of pollution in Bonaparte Street by a complex model which allow to valid wind field and to compare pollutants measurements with the Bonaparte street station data. The second one consists in comparing the results obtained by the simple model and by the complex one.

\subsection{Complex model}

The complex model is built from Bonaparte Street cadastre produced by the agency of town planning of the town of Paris (APUR). It gives us details of interior yard of the Beaux-arts school and the specific height of buildings of the zone around the station of measurements. The space is indented as a calculus grid (vertical and horizontal discretization) so as to solve by successive approximations the fluid mechanics equations. The grid is variable on both directions (vertical and horizontal) in order to give precise results around the measurements point (thin resolution from the first vertical metres so that the urban morphology be taken into account). The complex model includes 178200 cells (8100 cells for each horizontal layer and 22 vertical layers).
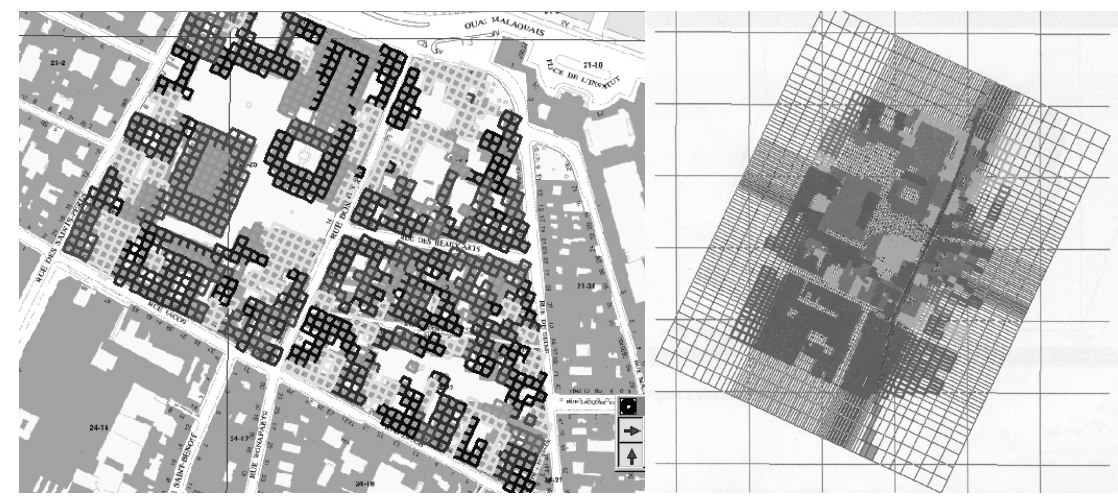

Figure 2: Cadastre map and buildings produced by the grid (left) and complex model (right). (Source: Kisters France SAS).

The wind field is initialised from Montsouris Meteo France wind data, at a scale which is not influenced by urban morphology, which means above the highest building of the considered zone $(500 \mathrm{~m})$. The wind field validation is 
making from data obtained between December $4^{\text {th }}$ and December $7^{\text {th }}, 2000$. The wind field vector is composed by three components $(\mathrm{u}, \mathrm{v}, \mathrm{w})$ which allow calculating the wind field resultant. This resultant is compared to the wind speed measured by the master. As the space is cut into cells, the real wind (height of the master: $4 \mathrm{~m}$ ) is compared to cells of 3-4.5 m layer. The results are the following:

Table 1: Levels, steps and associate heights of complex model (source: Kisters France SAS).

\begin{tabular}{|c|c|c|c|c|c|c|c|c|c|c|c|c|c|c|c|c|c|c|c|c|c|}
\hline Levels & $|1| 2$ & & 4 & 5 & 6 & 7 & 8 & 9 & 10 & 11 & 12 & 13 & 14 & 15 & & & 18 & 19 & 20 & 21 & 22 \\
\hline $\mathbf{S}$ & \begin{tabular}{|l|l|}
0 & 1
\end{tabular} & & 1,5 & $z$ & 2,5 & 7 & & 3 & 3 & & 4 & 5 & 7 & IU & 14 & 20 & 30 & 40 & 75 & 101 & 160 \\
\hline Height & \begin{tabular}{|l|l|}
1 & 2 \\
\end{tabular} & & 4,5 & 6,5 & 9 & 12 & 15 & 18 & 21 & 24 & 28 & 33 & 40 & 50 & 64 & 84 & 114 & 164 & 239 & 340 & 50 \\
\hline
\end{tabular}

Table 2: Wind Montsouris data, computations data by MISKAM complex model and measurements by mast. (Source: Kisters France SAS [4].)

\begin{tabular}{|l|c|c|c|c|c|c|c|c|}
\hline & \multicolumn{2}{|c|}{ Montsouris } & \multicolumn{3}{c|}{ MISKAM computations } & \multicolumn{2}{c|}{ Mast } \\
\hline Dates & Angle & $\vee \mathrm{m} / \mathrm{s}$ & $\begin{array}{c}\text { Average } \\
\text { component } \\
\mathrm{U}\end{array}$ & $\begin{array}{c}\text { Average } \\
\text { component } \\
\vee\end{array}$ & $\begin{array}{c}\text { Model } \\
\text { resultant }\end{array}$ & $\begin{array}{c}\text { Model angle } \\
\text { Mast Angle }\end{array}$ & $\begin{array}{c}\text { Mecity of } \\
\text { mast } \\
\text { (m/s) }\end{array}$ \\
\hline 7 TU 4 déc. & 200 & 4 & $-0,30$ & 1,50 & 1,5 & 194 & 211 & 2,2 \\
\hline 8 TU 4 déc. & 180 & 5 & $-0,44$ & 2,02 & 2,1 & 193 & 210 & 1,8 \\
\hline 7 TU 5 déc. & 170 & 4 & $-0,35$ & 1,51 & 1,5 & 192 & 212 & 1,4 \\
\hline 8 TU 5 déc. & 170 & 4 & $-0,35$ & 1,51 & 1,5 & 192 & 211 & 1,3 \\
\hline 7 TU 6 déc. & 190 & 4 & $-0,33$ & 1,51 & 1,5 & 193 & 206 & 1,56 \\
\hline 8 TU 6 déc. & 180 & 4 & $-0,35$ & 1,53 & 1,6 & 192 & 204 & 1,55 \\
\hline 7 TU 7 déc. & 130 & 3 & $-0,15$ & 0,76 & 0,8 & 194 & 207 & 0,9 \\
\hline 8 TU 7 déc. & 130 & 3 & $-0,15$ & 0,76 & 0,8 & 194 & 215 & 1 \\
\hline 9 TU 7 déc. & 130 & 3 & $-0,15$ & 0,76 & 0,8 & 194 & 212 & 0,9 \\
\hline
\end{tabular}

The table 2 shows good appropriateness between the model results and the master measurements. While the wind speed is well modelled, the direction cannot be estimated as precisely as the speed. This can be explicated by the master position in a zone where there is a lot of local turbulence. This turbulence is difficult to model with such a model because the size of the cells is too large to do this. The values of parameters calculated for each cell are average ones and could not show local fluctuations which sizes are inferior as cells size. The complex model gives a good representation of the real situation.

Once the wind field produced, the second step consists in producing pollutants concentrations fields (NOx and $\mathrm{CO}$ ). To analyse how wind fields dissipate the pollutants, a first work (linear sources measures) has been done. This consists in calculating the theoretical emissions according to the traffic (flow, composition, speed, and meteorological conditions). The average hourly concentrations were calculated by Airparif by means of EMITRA soft. The linear values of concentrations and wind field allow creating pollutants concentrations flow. In this article, it is rather difficult to present all the results, but we can say that the results obtained by simulation compared to those of Bonaparte station show good appropriateness of values. Nevertheless, there are some uncertainties about the results, whose origin is varied. This shows that some parameters are more influent. The most influential one on pollutants dispersion is the wind 
(velocity and direction), parameter which is directly determined by the urban morphology.

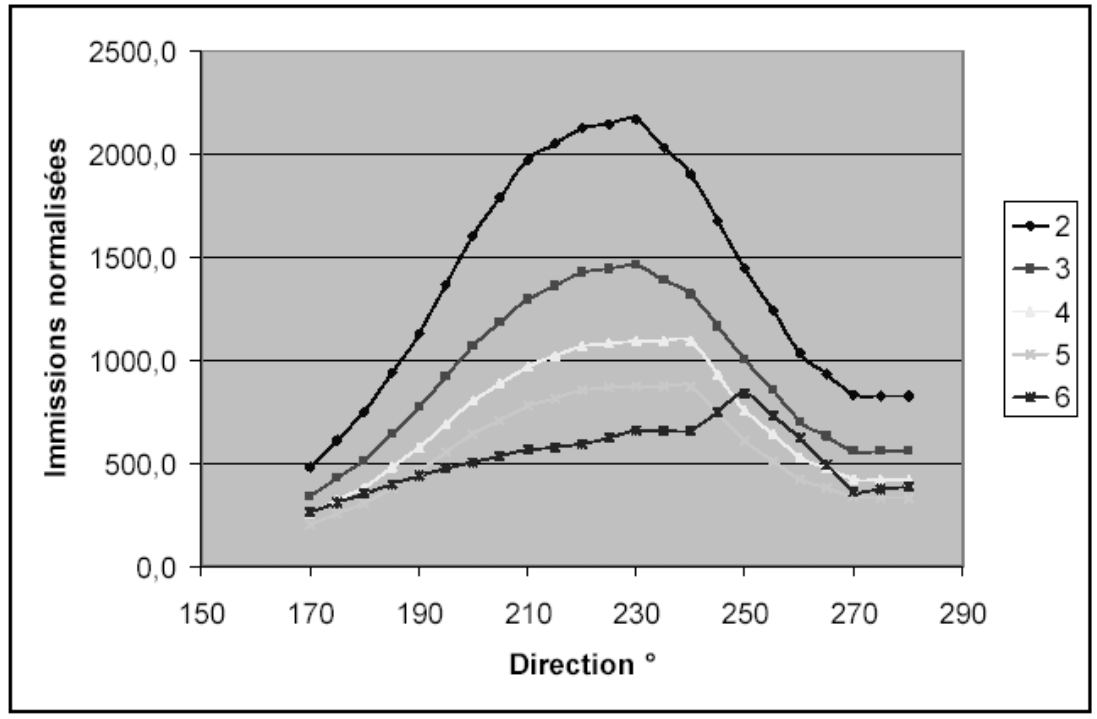

Figure 3: Influence of wind direction and velocity on normalised immissions rates (source: Kisters France SAS).

The figure 3 provides two pieces of information about the wind. Whatever the wind speed may be, there are privileged directions which increase concentrations rates. In our case the street direction is $115^{\circ}$, the $230^{\circ}$ direction is the worst. Concerning the wind speed, the lower it is, the higher immissions are. This means that the polluting winds are the slowest ones. For a $230^{\circ}$ direction, the $2 \mathrm{~m} / \mathrm{s}$ wind speed increases the immissions by a factor near to 4 compared to a $6 \mathrm{~m} / \mathrm{s}$ speed.

\subsection{Simple model}

The simple model consists in using a simplified typology for Bonaparte Street. In a simple typology, we do not consider urban morphology details, such as interior yard or buildings slides. The following parameters have been chosen:

- two way street - close buildings - index of construction of Landsberg (street size: $\mathrm{H} / \mathrm{L}=1 / 1$ ).

- 1400 vehicle per hour (statistic values of traffic data)

- A straight way with two ways of circulation

The simple model is composed by 200000 cells (10000 cells for each horizontal layer and 20 vertical layers).

With these elements, the simple model, which only takes into account the simple urban morphology around the station - Bonaparte Street and Beaux -Arts Street - is the following: 


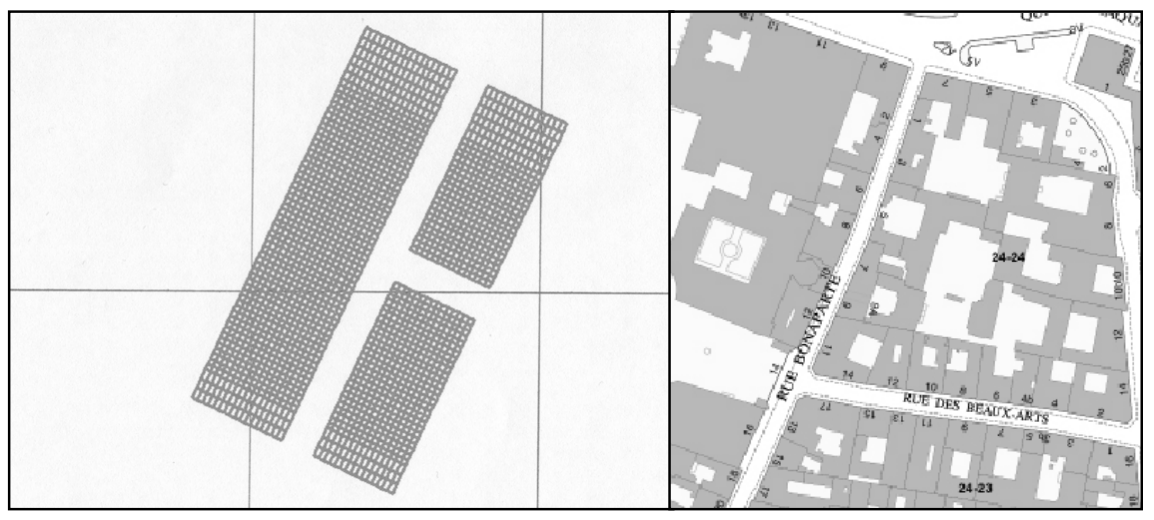

Figure 4: Simple model grid (source: Kisters France SAS) on the left and cadastre on the right (source: APUR).

The grid is regular on the street being studied (two metres in each horizontal direction $\mathrm{x}$ and $\mathrm{y}$ ) and variable with the distance of street axe. The vertical levels are variable and they are associated to the following grid.

Table 3: Levels, steps and associate heights of simple model (source: Kisters France SAS [4]).

\begin{tabular}{|c|c|c|c|c|c|c|c|c|c|c|c|c|c|c|c|c|c|c|c|}
\hline Lev & 12 & 23 & 4 & 5 & 6 & 7 & 8 & 9 & 10 & 11 & 12 & 13 & 14 & 15 & 16 & 17 & 18 & 19 & 0 \\
\hline Steps & \begin{tabular}{|l|l|}
0 & 1 \\
\end{tabular} & 12 & 2 & 2 & 2 & 2 & 2 & 2 & 2 & 2 & 2 & 2 & 2 & 4 & 10 & 10 & 100 & 100 & 15 \\
\hline eight & 12 & \begin{tabular}{|l|l|}
2 & 4 \\
\end{tabular} & 6 & 8 & 10 & 12 & 14 & 16 & 18 & 20 & 22 & 24 & 26 & 30 & 40 & 50 & 150 & 250 & 400 \\
\hline
\end{tabular}

As the urban Bonaparte street morphology is complex, the results produced by the simple model must be compared to the results of the complex model. The comparison relies on two points: wind (velocity and direction) and concentrations fields. The following table shows the results of simulated wind produced by the simple model and the complex one.

Table 4: Wind simulations results obtained by the simple model and by the complex one. (Source: Kisters France SAS [4]).

\begin{tabular}{|c|c|c|c|c|c|c|c|c|}
\hline & \multicolumn{1}{|c|}{ Computations MISKAM simple model } & \multicolumn{3}{|c|}{ Computations MISKAM complex model } \\
\hline Dates & $\mathbf{u}$ & $\mathbf{v}$ & $\mathbf{R}$ & Angle & $\mathbf{u}$ & $\mathbf{v}$ & $\mathbf{R}$ & Angle \\
\hline 7 TU 4 déc. & 0,02 & 2,21 & 2,21 & 204,39 & $-0,30$ & 1,50 & 1,53 & 193,60 \\
\hline 8 TU 4 déc. & 0,13 & 2,79 & 2,79 & 202,33 & $-0,44$ & 2,02 & 2,06 & 192,70 \\
\hline 7 TU 5 déc. & 0,13 & 2,16 & 2,16 & 201,55 & $-0,35$ & 1,51 & 1,55 & 192,02 \\
\hline 8 TU 5 déc. & 0,13 & 2,16 & 2,16 & 201,55 & $-0,35$ & 1,51 & 1,55 & 192,02 \\
\hline 7 TU 6 déc. & 0,06 & 2,26 & 2,26 & 203,39 & $-0,33$ & 1,51 & 1,54 & 192,74 \\
\hline 8 TU 6 déc. & 0,10 & 2,24 & 2,25 & 202,45 & $-0,35$ & 1,53 & 1,57 & 192,20 \\
\hline 7 TU 7 déc. & 0,15 & 0,75 & 0,76 & 193,64 & $-0,15$ & 0,76 & 0,77 & 193,58 \\
\hline 8 TU 7 déc. & 0,15 & 0,75 & 0,76 & 193,64 & $-0,15$ & 0,76 & 0,77 & 193,58 \\
\hline 9 TU 7 déc. & 0,15 & 0,75 & 0,76 & 193,64 & $-0,15$ & 0,76 & 0,77 & 193,58 \\
\hline
\end{tabular}


As the results (table 4) show it, the simple model overestimates the wind. In fact, as it is more morphologically simpler, the wind flow is accelerated and phenomena of complex turbulence, created by urban morphology details, are eliminated.

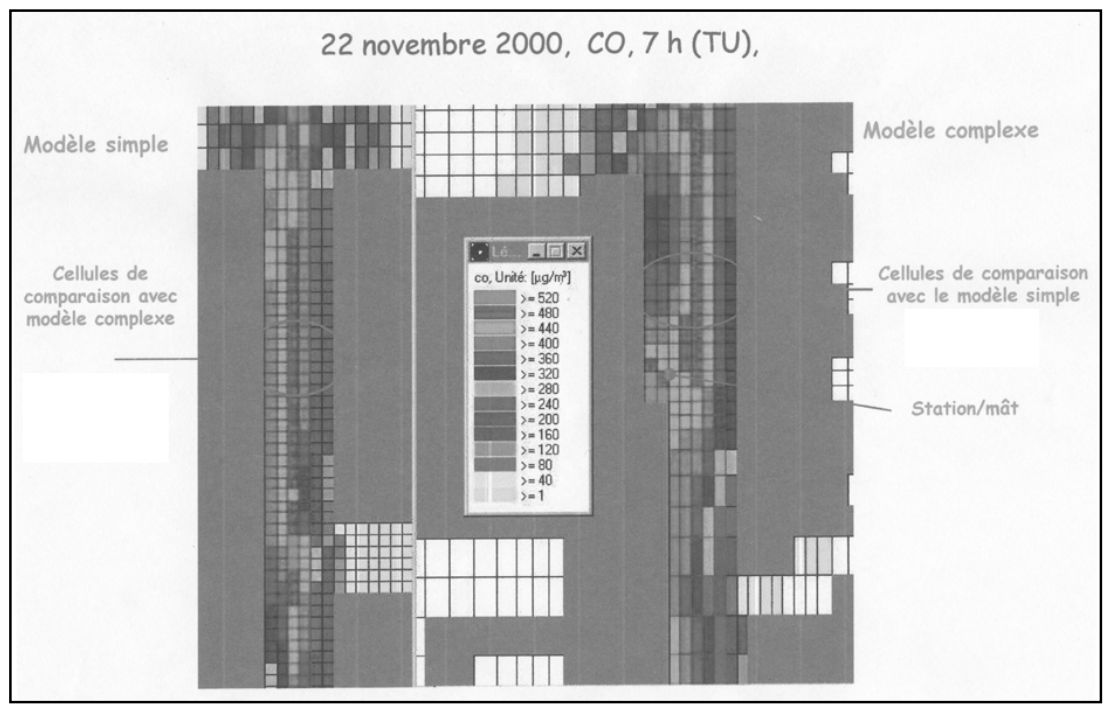

Figure 5: Comparison of carbon monoxide concentrations obtained by the simple model and the complex model: example of November $22^{\text {nd }}$, 2000 at $7 \mathrm{~h}$ TU. (Source: Kisters France SAS).

The comparison between concentrations produced by the simple model and by the complex model is made cell by cell. The difference of values between cells is insignificant and the performance of the simple model confronted to meteorological fluctuations is the same as that of the complex model.

\section{Conclusion}

Even if the simple model overestimates the wind, it gives us good measurements for pollutants concentrations, which let us think that it could be used in real time. In fact, the complex model is more suitable to understand the wind phenomenon and to predict concentrations in each cell. But it is time-consuming for computers (CPU) which makes it non - operational for a current use, taking into account computers performances. If we need to study the concentrations fields in each point of the space, with the minimum of errors, we will have to use the complex model. But if we want to create an operational tool able to control the air city quality in real time, its main characteristic must be rapidity. The simple model fulfils this condition. 


\section{References}

[1] Hassan A.A.., Crowther J.M.., Modelling of fluid flow and pollutant dispersion in a street canyon, Environmental Monitoring and Assessment, Vol. 52, n¹-2, pp. 281-297, 1998.

[2] Karppinen A., Kukkonen J., Elolahde T., Konttinen M., Koskentalo T., A modelling system for predicting urban air pollution: comparison of model predictions with the data of an urban measurement network in Helsinki, Atmospheric Environment, Vol. 34, pp. 3735-3743, 2000.

[3] Kastler A., Mathieu J.P., Fleury P., Dictionnaire de physique, troisième édition, Masson, 568 p, 1991.

[4] Kisters France SAS, Rapport final relatif à l'étude de faisabilité, Airparif, $71 \mathrm{p}, 2001$.

[5] Maignant G., Pollution et développement durable des villes françaises, étude de cas: Nice, Marseille, Lyon et Paris. Thèse de Doctorat en géographie de l'Université de Nice Sophia-Antipolis, 3 volumes $460 p+1$ atlas de 135 pages, 2002.

[6] Qyn Y., Kot S.C., Dispersion of vehicular emission in street canyons, Guangzhou City, South (P.R.C), Atmospheric Environment, Vol. 27B, n³, pp. 283-291, 1993.

[7] Tarnier P., Le scandale de l'air contaminé, Mango, 196 p, 2001.

[8] Ung A., Ranchin T., Wald L., Weber C., Hirsch J., Perron G., Kleinpeter J., Cartographie de la pollution de l'air: une nouvelle approche basée sur la télédétection et les bases de données géographiques. Application à la ville de Strasbourg, Journées CASSINI 2002 du GDR Cassini-Sigma, 14 p, 2002.

[9] Vardoulakis S., Fisher B.E.A., Pericleous K., Gonzalez-Flesca N., Modelling air quality in street canyons: a review, Atmospheric Environment, Vol. 37, n², pp. 155-182, 2003.

[10] Zanetti P., Air pollution modelling. Theories, Computational Methods and Available Software, Computational Mechanics Pubbl. Southampton \& Boston, 1990. 